\title{
Perbandingan Reaksi Pasar pada Perusahaan LQ45 dan Non LQ45 atas Pengumuman Stock Split
}

\author{
Kadek Wahyudi ${ }^{1}$ \\ Fakultas Ekonomi dan Bisnis \\ Universitas Udayana, Indonesia \\ Email: wahyudikadek15@gmail.com
}

\author{
I Nyoman Wijana Asmara Putra ${ }^{2}$ \\ Fakultas Ekonomi dan Bisnis \\ Universitas Udayana, Indonesia
}

\begin{abstract}
ABSTRAK
Pengumuman stock split dipercaya dapat menimbulkan reaksi investor. Perusahaan indeks LQ45 yang sudah memiliki likuiditas tinggi di BEI ada yang melakukan stock split. Penelitian ini bertujuan menguji perbedaan reaksi pasar perusahaan LQ45 sebelum dan sesudah pengumuman stock split, menguji perbedaan reaksi pasar perusahaan non LQ45 sebelum dan sesudah pengumuman stock split, dan menguji perbedaan reaksi pasar antara perusahaan LQ45 dan non LQ45 atas pengumuman stock split. Sampel penelitian ini adalah perusahaan yang melakukan stock split up selama Januari 2007-Juli 2019. Reaksi pasar diukur dengan abnormal return. Teknik analisis yang digunakan adalah uji beda. Hasil penelitian menunjukkan terdapat reaksi pasar perusahaan LQ45 dan non LQ45 atas pengumuman stock split, dan terdapat perbedaan reaksi pasar antara perusahaan LQ45 dan non LQ45 atas pengumuman stock split.
\end{abstract}

Kata Kunci: Stock Split; Perbedaan Abnormal Return; Reaksi Pasar.

\section{Comparison of Market Reactions to Companies LQ45 and Non LQ45 on Stock Split Announcement}

\section{ABSTRACT}

Stock split announcements are believed to cause investor reaction. The $L Q 45$ Index company that already has high liquidity in IDX is a stock split. This research aims to test the difference of the company's market reaction LQ45 before and after the stock split announcement, test the reaction difference of the non-LQ45 company market before and after the stock split announcement, and test the market reaction difference between LQ45 and non LQ45 companies on the stock split announcement. This research sample is a company that does stock split up during January 2007-July 2019. Market reactions are measured by abnormal return. The analytical techniques used are different tests. The results showed there was a reaction of the company's market $L Q 45$ and non LQ45 on the stock split announcement, and there was a difference in market reaction between $L Q 45$ and non-LQ45 companies over stock split announcements.

Keywords: Stock Split; Abnormal Return Difference; Market Reaction.

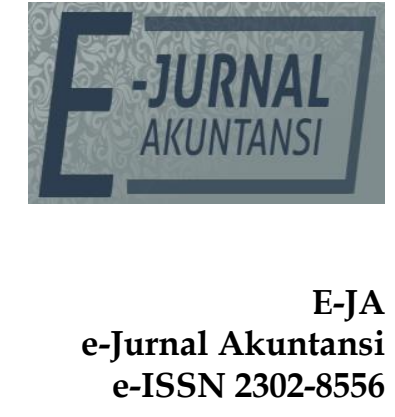

Vol. 30 No. 2

Denpasar, Februari 2020

Hal. 307-318

Artikel Masuk: 23 September 2019

Tanggal Diterima: 6 November 2019 


\section{PENDAHULUAN}

Stock split merupakan memecah selembar saham menjadi $\mathrm{n}$ lembar saham (Hartono, 2017: 649). Stock split menambah banyaknya saham perusahaan yang beredar, namun menurunkan harga dari saham per lembar tersebut (Hua \& Ramesh, 2013). Peristiwa stock split yang dilakukan oleh perusahaan tidak menambah nilai dari perusahaan, melainkan hanya memengaruhi nominal saham. Namun, emiten tetap melakukan stock split untuk membuat rendah harga dari saham yang dinilai masih tinggi dan perusahaan beranggapan dengan harga saham yang lebih rendah akan menarik investor untuk berinvestasi. Secara teoretis, pemegang saham tidak memperoleh keuntungan nyata dari peristiwa stock split, meskipun ada biaya yang dikeluarkan untuk itu (Korir et al., 2016). Biasanya, perusahaan yang likuiditas rendah saja yang melakukan stock split, namun masih ada perusahaan indeks LQ45 yang berlikuiditas tinggi melakukan stock split. Perusahaan LQ45 adalah 45 perusahaan yang memiliki kapitalisasi pasar besar dan likuiditas tinggi serta memiliki fundamental yang baik. Data Bursa Efek Indonesia menunjukkan, dari 145 aksi stock split yang dilakukan perusahaan selama Januari 2007 hingga Juli 2019, terdapat 15 aksi yang dilakukan oleh perusahaan dengan indeks LQ45.

Perusahaan dengan indeks LQ45 yang melakukan stock split, yaitu PT Telekomunikasi Indonesia (Persero) Tbk. (TLKM). Pada hari pertama pengumuman stock split, TLKM mendapatkan respon positif dari pasar dengan berhasil mencapai kenaikkan dari harga pembukaan Rp2.025 per lembar saham menjadi Rp2.150. Perusahaan dengan indeks LQ45 lainnya yaitu Bank Mandiri (Persero) Tbk. (BMRI) mengalami penurunan pada hari pertama, dari harga Rp6.600 per lembar saham menjadi Rp6.575. Namun, pada hari ketiga pengumuman stock split, harga BMRI mengalami kenaikkan menjadi Rp6.625. Perusahaan non LQ45 yang melakukan stock split seperti Surya Toto Indonesia Tbk. (TOTO), pada hari pertama mendapatkan respon positif dari pasar, dengan mencapai kenaikkan 19,85\% dari harga pembukaan Rp3.400 menjadi Rp4.075 per lembar saham. Perusahan lainnya yaitu Mark Dynamics Indonesia Tbk. (MARK), pada hari pertama sampai kedua pengumuman stock split, saham MARK mendapatkan respon positif dari pasar, dengan harga pembukaan Rp422 per lembar saham menjadi Rp428, dan pada hari ketiga mengalami kenaikkan menjadi Rp505 per lembar saham. Adanya reaksi yang beragam dari investor mengenai stock split mengindikasikan bahwa aksi korporasi ini memberikan sinyal bagi investor.

Pengumuman stock split dipercaya investor akan menghasilkan pembelian saham, maka harga saham cenderung akan meningkat dan menghasilkan return yang lebih (Desai, 2016). Return merupakan imbalan investasi yang dilakukan dengan cara membeli saham. Selisih dari return yang sesungguhnya terjadi terhadap return normal disebut dengan abnormal return (Hartono, 2017: 667).

Beberapa peneliti mencoba melakukan penelitian mengenai reaksi pasar terhadap pengumuman stock split dan memperlihatkan hasil penelitian yang beragam. Penelitian yang dilakukan oleh Tabibian \& Zhang (2018), Karim et al., (2018), dan Hanafie \& Diyani (2016) menghasilkan bahwa adanya abnormal return yang positif atas pengumuman stock split selama periode amatan. Penelitian Patel 
et al., (2016), Trijunanto (2015), dan Adnyani \& Putri (2015) menyatakan bahwa tidak adanya return tak normal di perode amatan pada pengumuman stock split.

Penelitian sebelumnya memperlihatkan hasil yang beragam terkait stock split, hal ini bisa dipengaruhi oleh lamanya penelitian atau objeknya, sehingga sampel yang didapatkan berbeda-beda. Periode pada penelitian selama 13 tahun, yaitu dari tahun 2007-2019, alasannya untuk mendapatkan lebih banyak jumlah perusahaan dengan indeks LQ45 yang melakukan stock split. Oleh karena itu, diperlukan waktu yang panjang untuk mendapatkan sampel, sehingga memperoleh hasil yang lebih akurat.

Teori sinyal didasarkan pada informasi yang diterima oleh masingmasing pihak berbeda. Teori sinyal menyatakan bahwa setiap aksi korporasi yang dilakukan sebuah perusahaan memiliki potensi kandungan informasi sebagai suatu sinyal (Pratama \& Sudhiarta, 2014). Pengumuman stock split merupakan sinyal bagi investor bahwa perusahaan mempunyai prospek kinerja yang positif. Adanya asimetri informasi dimana manajer perusahaan lebih mengetahui prospek perusahaan dibandingkan dengan investor, memungkinkan manajer perusahaan untuk menyampaikan sinyal baik kepada investor dan diharapkan menimbulkan respon yang positif dari pengumuman stock split. Teori sinyal mengungkapkan..bahwa stock split membawa kandungan informasi..mengenai prospek..peningkatan return masa depan (Kalay \& kronlund, 2012). Adanya pengumuman stock split artinya pemegang saham diberikan sinyal oleh perusahaan. Pengumuman stock split memberikan sinyal kepada pemegang saham tentang harapan masa depan perusahaan.

Trading range theory menyatakan aksi stock split akan mengurangi harga saham dalam kisaran reguler ke investor ritel, hal ini akan memungkinkan lebih banyak investor untuk memperjualbelikan saham (Nagendra \& Suresh, 2018). Trading range theory menyatakan bahwa aktifnya harga saham diperjualbelikan di pasar modal akibat dari harga saham yang lebih murah. Dilakukannya stock split mengakibatkan harga dari saham menjadi lebih mudah dijangkau bagi investor, sehingga saham akan menjadi lebih likuid dan dengan meningkatnya permintaan saham akan meningkatkan harga saham (Hossain, 2017).

Indeks LQ45 adalah nilai kapitalisasi pasar dari 45 saham yang paling likuid di BEI. Indeks LQ45 menggunakan 45 saham yang terpilih berdasarkan likuiditas perdagangan saham dan disesuaikan setiap enam bulan sekali. Indeks LQ45 digunakan untuk menyediakan sarana yang obyektif dan terpercaya bagi analisis keuangan dalam memonitor pergerakan harga dari saham-saham yang aktif diperdagangkan.

Studi peristiwa merupakan analisis empiris yang digunakan untuk menilai efek dari suatu peristiwa dengan return saham (Nadig, 2015). Fungsi event study yaitu untuk menguji kandungan informasi dari suatu pengumuman, dalam hal ini adalah pengumuman stock split. Fungsi studi peristiwa digunakan untuk menganalisi suatu kandungan peristiwa dari suatu informasi atau pengumuman. Pengumuman stock split dikatakan memiliki informasi jika terdapat abnormal return.

Stock split mengakibatkan harga saham menjadi lebih dijangkau dari sebelumnya. Investor yang awlanya tidak bisa menjangkau harga saham tersebut, dengan dilakukannya stock split dapat dijangkau. Banyaknya 
pengumuman stock split yang dilakukan oleh emiten, memberikan maksud bahwa stock split merupakan sesuatu hal yang berguna dalam praktik pasar modal karena stock split menjadi salah satu aksi korporasi bagi perusahaan untuk membuat saham menjadi lebih likuid.

Kerangka konseptual pada penelitian ini ditampilkan pada Gambar 1. berikut ini.

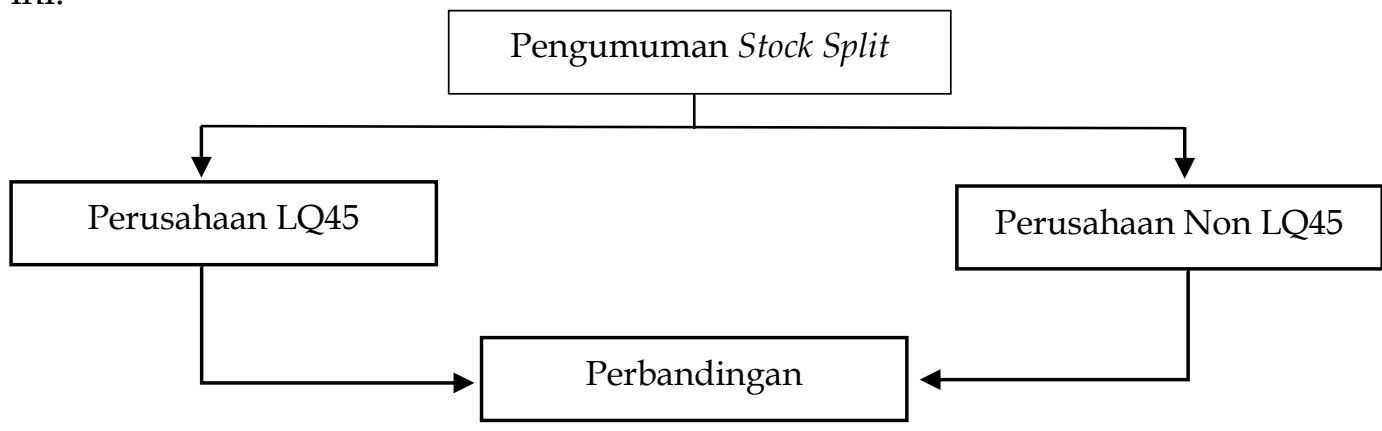

Sumber: Data Penelitian, 2019

\section{Gambar 1. Kerangka Konseptual}

Penelitian Artama \& Wirakusuma (2018) dan Paramitha (2019) menunjukan hasil adanya reaksi pasar posiitiif saat pengumuman stock split yang diukur menggunakan return tak normal. Perusahaan LQ45 sangat diminati oleh investor karena perusahaan LQ45 memiliki fundamental yang baik. Perusahaan indeks LQ45 sangat banyak diminati oleh investor. Perusahaan LQ45 yang melakukan stock split akan dimanfaatkan investor retail untuk berinvestasi di perusahaan yang liquid dan kapitalisasi pasar besar serta didukung oleh fundamental perusahaan yang baik dengan harga yang relatif lebih murah akibat dari stock split. Hipotesis yang dapat ditarik yaitu.

$\mathrm{H}_{1}$ : Terdapat perbedaan reaksi pasar perusahaan LQ45 sebelum dan sesudah pengumuman stock split.

Menurut Griffin (2010), Investor akan bereaksi terhadap suatu pengumuman di pasar modal apabila hal tersebut memiliki kandungan informasi yang membawa sinyal berkualitas dan dapat dipercaya. Adanya pengumuman stock split artinya perusahaan memberikan sinyal kepada pemegang saham tentang harapan masa depan perusahaan. Penelitian Jain \& Robbani (2013) dan Putra \& Suaryana (2019) menunjukkan bahwa pasar merespon secara positif dengan pengumuman stock split yang dilakukan oleh emiten. Pengumuman dari stock split merupakan peristiwa yang dinanti oleh investor, khususnya investor retail. Perusahaan yang diluar indeks LQ45 memiliki keinginan yang lebih untuk melakukan pengumuman stock split agar saham perusahaan mereka menjadi likuid. Hipotesis yang dapat ditarik yaitu.

$\mathrm{H}_{2}$ : Terdapat perbedaan reaksi pasar perusahaan non LQ45 sebelum dan sesudah pengumuman stock split.

Pemecahan saham dapat dipandang sebagai sinyal bahwa perusahaan memiliki kinerja yang lebih baik atau minimal mempunyai potensi peningkatan kinerja perusahaan pada masa mendatang (Khajar, 2016). Akibat dari stock split, harga saham perusahaan LQ45 semakin diminati invetor dibanding dengan perusahaan lain. Memiliki keunggulan seperti itu membuat investor lebih tertarik berinvestasi di perusahaan dengan indeks LQ45. Indeks LQ45 dikenal 
perusahaan yang liquid dan kapitalisasi pasar besar serta didukung oleh fundamental perusahaan yang bagus. Ini sesuai dengan hasil penelitian yang dilakukan oleh Jannah \& Ady (2017), bahwa analisis fundamental berpengaruh terhadap keputusan berinvestasi investor. Hipotesis yang dapat ditarik yaitu.

$\mathrm{H}_{3}$ : Terdapat perbedaan reaksi pasar antara perusahaan LQ45 dan non LQ45 atas pengumuman stock split.

\section{METODE PENELITIAN}

Pendekatan yang digunakan dalam penelitian ini termasuk ke dalam kategori event study atau studi peristiwa. Studi peristiwa merupakan analisis empiris yang digunakan untuk menilai efek dari suatu peristiwa dengan return saham (Nadig, 2015). Fungsi studi peristiwa digunakan untuk menganalisis suatu kandungan peristiwa dari suatu informasi atau pengumuman. Pengumuman dikatakan memiliki informasi jika disekitar pengumuman dari stock split ditemukan abnormal return. Peristiwa yang diuji dalam penelitian ini adalah pengumuman stock split yang diukur menggunakan abnormal return selama 5 hari amatan. Data yang digunakan adalah data sekunder, dimana data yang diperoleh melalui website resmi Bursa Efek Indonesia.

Variabel yang digunakan dalam penelitian ini adalah variabel tunggal. Variabel tunggal dalam penelitian ini adalah reaksi pasar atas pengumuman stock split yang diukur dengan abnormal return. Penelitian ini menggunakan market adjusted model untuk mengestimasi return ekspetasiannya, karena abnormal return dapat dideteksi dengan mudah menggunakan market adjusted model, dengan periode amatan selama 5 hari, yaitu 2 hari sebelum pengumuman, 1 hari pada saat pengumuman, dan 2 hari setelah pengumuman dilakukan. Populasi dalam penelitian ini adalah seluruh perusahaan yang terdaftar di Bursa Efek Indonesia yang melakukan stock split selama Januari 2007-Juli 2019. Metode penentuan sampel pada penelitian ini adalah nonprobability sampling dengan teknik purposive sampling dengan beberapa kriteria, yaitu: 1) Perusahaan yang terdaftar di BEI yang melakukan stock split up yang tergolong LQ45 dan non LQ45 selama Januari 2007-Juli 2019, 2) Perusahaan yang tidak melakukan corporate action lain selain stock split, 3) Perusahaan..yang datanya..tersedia secara lengkap. Untuk mengumpulkan data menggunaka metode observasi nonpartisipan, yaitu mencatat data dari arsip-arsip maupun internet yang relevan dengan data yang dibutuhkan untuk kebutuhan analisis penelitian

Analisis data yang akan digunakan pertama adalah uji statistik deskriptif, selanjutnya adalah uji normalitas dengan uji statistik kolmogorov-smirnov untuk mengetahui apakah data berdistribusi normal atau tidak. Data berdistribusi normal bila nilai signifikansi lebih dari 0,05. Pengujian hipotesis pertama menggunakan uji wilcoxon signed ranks test, yaitu uji non parametrik yang digunakan untuk membandingkan rata-rata abnormal return sebelum dan sesudah pada perusahaan LQ45 atas pengumuman stock split. Pengujian hipotesis yang kedua menggunakan uji..paired sample t-test, yaitu uji parametrik yang digunakan untuk menguji perbedaan reaksi pasar sebelum dan sesudah pada perusahaan non LQ45 atas pengumuman stock split. Hipotesis ketiga menggunakan uji independent sample t-test untuk membandingkan reaksi pasar antara perusahaan LQ45 maupun yang non LQ45 atas pengumuman stock split. 


\section{HASIL DAN PEMBAHASAN}

Data penelitian ini adalah perusahaan yang terdaftar di BEI yang melakukan pengumuman stock split yang tergolong perusahaan LQ45 dan non LQ45 selama Januari 2007 sampai dengan Juli 2019. Selama Januari 2007 sampai dengan Juli 2019, terdapat 145 perusahaan yang melakukan aksi stock split, 15 diantaranya adalah perusahaan LQ45. Berikut Tabel 1. yang memperlihatkan secara rinci proses seleksi sampel penelitian.

Tabel 1. Seleksi Sampel Penelitian

\begin{tabular}{|c|c|c|c|}
\hline \multirow{2}{*}{ No } & \multirow{2}{*}{ Kriteria } & \multicolumn{2}{|c|}{ Stock split } \\
\hline & & LQ45 & Non LQ45 \\
\hline 1 & $\begin{array}{l}\text { Perusahaan yang terdaftar di BEI yang melakukan } \\
\text { stock split up yang tergolong LQ45 dan non LQ45 } \\
\text { selama Januari 2007-Juli } 2019\end{array}$ & 15 & 130 \\
\hline 2 & Perusahaan yang melakukan aksi korporasi lain & - & (1) \\
\hline 3 & Perusahaan datanya tidak tersedia secara lengkap & - & (38) \\
\hline \multicolumn{2}{|c|}{ Jumlah sampel } & 15 & 91 \\
\hline
\end{tabular}

Sumber: Data Penelitian, 2019

Berdasarkan Tabel 1., diperoleh 15 perusahaan LQ45 dan 130 perusahaan non LQ45. Namun satu perusahaan non LQ45 yaitu PT Surya Toto Indonesia Tbk. (TOTO) melakukan kebijakan dividen saham selama periode pengamatan. Terdapat 38 perusahaan non LQ45 datanya tidak tersedia. Dengan demikian, terdapat 15 perusahaan LQ45 dan 91 perusahaan non LQ45 yang memenuhi kriteria untuk dianalisis. Uji statistik deskriptif digunakan untuk memberikan deskripsi dari data yang dapat dilihat dari jumlah sampel, maksimum, minimum, rata-rata, dan standar deviasi. Berikut uji statistik deskriptif pada Tabel 2.

\section{Tabel 2. Hasil Uji Statistik Deskriptif}

\begin{tabular}{llllll}
\hline Variabel & N & Minimum & Maksimum & Rata-Rata & $\begin{array}{l}\text { Standar } \\
\text { Deviasi }\end{array}$ \\
\hline AAR LQ45 Sebelum & 15 & $-0,017$ & 0,017 & $-0,001$ & 0,012 \\
AAR LQ45 Sesudah & 15 & $-0,010$ & 0,089 & 0,019 & 0,025 \\
AAR Non LQ45 Sebelum & 91 & $-0,040$ & 0,041 & 0,002 & 0,017 \\
AAR Non LQ45 Sesudah & 91 & $-0,026$ & 0,043 & 0,015 & 0,018 \\
AAR LQ45 & 15 & $-0,006$ & 0,019 & 0,009 & 0,007 \\
AAR Non LQ45 & 91 & $-0,035$ & 0,040 & 0,010 & 0,017 \\
\hline
\end{tabular}

Sumber: Data Penelitian, 2019

Hasil statistik deskriptif AAR sebelum pengumuman Perusahaan LQ45 memperoleh minimum -0,017, maksimum 0,017, memiliki rata-rata $-0,001$, dan nilai standar deviasi 0,012. AAR sesudah pengumuman perusahaan LQ45 memperoleh minimum -0,010, maksimum 0,089, rata-rata -0,019, dan dengan standar deviasi 0,025 . AAR sebelum pengumuman perusahaan non LQ45 memperoleh minimum -0,040, maksimum 0,041, rata-rata $-0,002$, dan dengan standar deviasi 0,017. AAR sesudah pengumuman perusahaan non LQ45 memperoleh minimum -0,026, maksimum 0,043, rata-rata -0,015, dan dengan standar deviasi 0,018. AAR perusahaan LQ45 memperoleh minimum -0,006, maksimum 0,019, rata-rata $-0,009$, dan dengan standar deviasi 0,007. AAR perusahaan non LQ45 memperoleh minimum -0,035, maksimum 0,040, rata-rata - 
0,010, dan dengan standar deviasi 0,017. Uji hipotesis pertama tidak menggunakan uji normalitas karena jumlah sampe perusahaan LQ45 kurang dari 30, sehingga uji hipotesis pertama menggunakan uji non parametrik yaitu wilcoxon signed ranks test, hasil pegujian wilcoxon signed ranks test dapat dilihat pada Tabel 3.

Tabel 3 Hasil Uji Wilcoxon Signed Ranks Test

\begin{tabular}{ll}
\hline & AAR Sesudah - AAR Sebelum \\
\hline$Z$ & $-2,613$ \\
Asymp. Sig. (2-tailed) & 0,009 \\
\hline Suber Dat Pend
\end{tabular}

Sumber: Data Penelitian, 2019

Berdasarkan Tabel 3. menunjukkan nilai asymp. Sig. (2-tailed) 0,009 lebih kecil dari 0,05. Dari hasil uji wilcoxon signed ranks test tersebut, dapat disimpulkan bahwa hipotesis pertama diterima atau terdapat perbedaan reaksi pasar perusahaan LQ45 sebelum dan sesudah pengumuman stock split. Hasil ini menunjukkan pengumuman stock split yang telah dilakukan oleh perusahaan LQ45 direaksi positif oleh pasar karena investor mengganggap pengumuman stock split bernilai ekonomis. Sinyal dari perusahaan yang kondisi fundamentalnya terpercaya akan direspon oleh investor. Reaksi pasar yang sejalan dengan teori sinyal dapat disebabkan karena investor menganggap pengumuman stock split yang dilakukan oleh perusahaan LQ45 merupakan berita baik. Hasil ini sesuai dengan penelitian yang dilakukan oleh Utami (2017) dan Zhu \& Chen (2014) yang menunjukkan bahwa terdapat abnormal return pada peristiwa stock split.

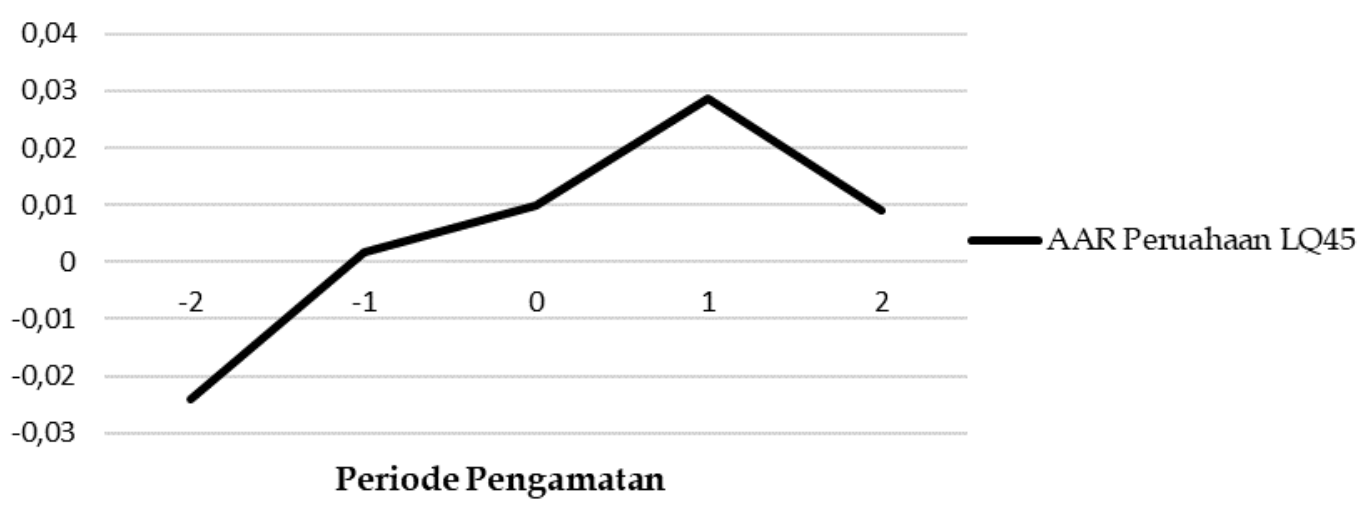

Sumber: Data Penelitian, 2019

\section{Gambar 2. Grafik Pergerakan AAR Perusahaan LQ45}

Berdasarkan Gambar 1., pergerakan rata-rata abnormal return cenderung meningkat mulai dari $\mathrm{t}-1$ hingga mencapai puncaknya pada $\mathrm{t}+1$ atau sehari setelah pengumuman stock split dilakukan oleh perusahaan LQ45. Namun pergerakannya menurun pada 2 hari setelah pengumuman dilakukan. Rata-rata return tak normal sebelum pengumuman sebesar -0,001, sedangkan sesudah pengumuman sebesar 0,019, artinya terjadi peningkatan rata-rata return tak normal setelah pengumuman dilakukan. Perusahaan LQ45 yang melakukan stock split membuat investor berekspetasi tinggi, karena investor bisa memiliki saham perusahaan LQ45 yang memliki likuiditas tinggi dan kapitalisasi pasar besar serta didukung oleh fundamental perusahaan yang baik dengan harga yang lebih murah akibat dari stock split. Akibat dari stock split, saham dari perusahaan 
LQ45 menjadi lebih terjangkau bagi investor retail, sehingga pasar memberikan reaksi.

Uji hipotesis kedua dilakukan uji..normalitas data dengan menggunakan..uji statistik kolmogorov-smirnov. Bila kedua data telah berdistribusi normal, maka bisa dilanjutkan ke uji parametrik yaitu uji paired sample t-test untuk menguji perbedaan reaksi pasar perusahaan LQ45 sebelum dan sesudah pengumuman stock split. Hasil dari uji normalitas sebelum pengumuman sebesar $0,163>0,05$ dan sesudah pengumuman sebesar 0,097 >0,05. Sehingga dapat dinyatakan kedua data berdistribusi normal untuk dilanjutkan ke uji paired sample t-test, dan dapat dilihat Hasil pengujian pada Tabel 4.

Tabel 4. Hasil Uji Paired Sample T-Test

\begin{tabular}{lllll}
\hline $\mathrm{N}$ & Rata-rata Sebelum & $\begin{array}{l}\text { Rata-rata } \\
\text { Sesudah }\end{array}$ & $\mathrm{t}$ & Sig. (2-tailed) \\
\hline 91 & 0,002 & 0,015 & $-5,244$ & 0,000 \\
\hline
\end{tabular}

Sumber: Data Penelitian, 2019

Hasil uji paired sample t-test memperlihatkan rata-rata sebelum pengumuman stock split sebesar 0,002 dan rata-rata abnormal return sesudah pengumuman stock split sebesar 0,015. Nilai t sebesar -5,244 dan asymp. Sig.. (2tailed) 0,000 lebih kecil dari 0,05 maka hipotesis kedua diterima atau terdapat perbedaan reaksi pasar perusahaan non LQ45 sebelum dan sesudah pengumuman stock split. Hasil ini mengkonfirmasi teori sinyal, dan hasil ini menjelaskan bahwa hanya perusahaan yang memiliki kinerja baik saja yang dapat mengirimkan sinyal baik ke investor. Investor memandang bahwa peristiwa stock split yang dilakukan perusahaan non LQ45 membawa sinyal yang baik (good news). Adanya pengumuman stock split artinya perusahaan memberikan sinyal kepada pemegang saham tentang harapan masa depan perusahaan. Hasil penelitian ini sesuai dengan penelitian Li et al., (2010) yang menunjukkan bahwa terdapat abnormal return pada peristiwa stock split.

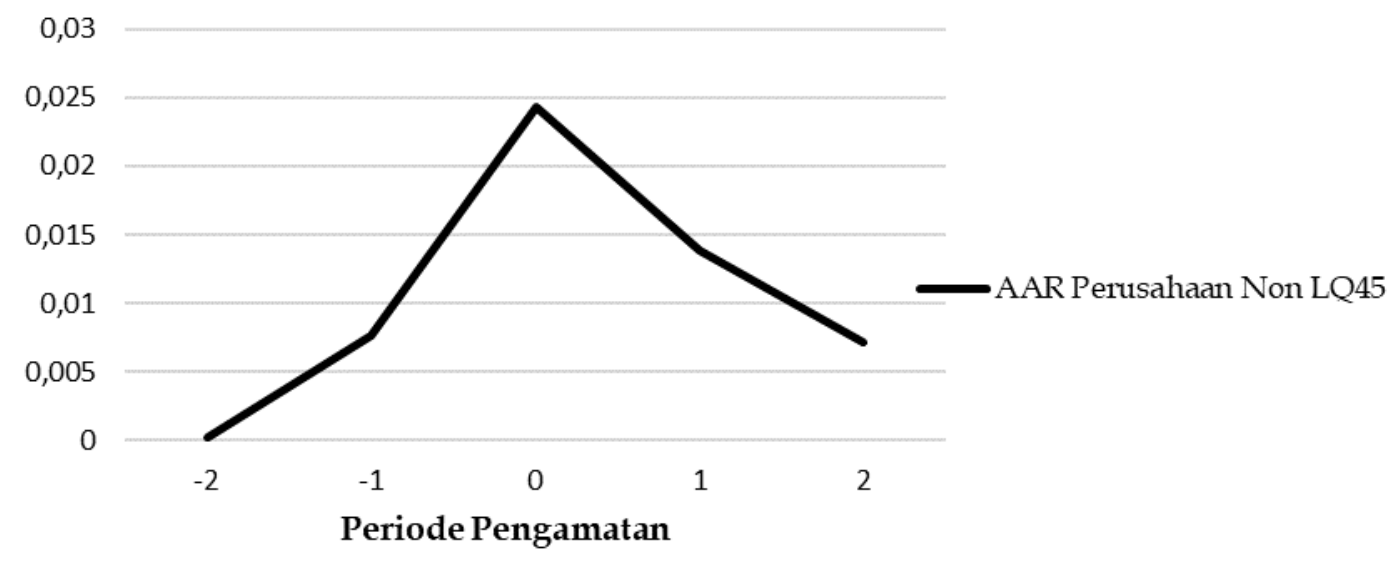

\section{Gambar 3. Grafik Pergerakan AAR Perusahaan Non LQ45}

Sumber: Data Penelitian, 2019

Berdasarkan Gambar 2., pergerakan average abnormal return mulai meningkat dari t-1 dan mencapai puncak tertinggi pada t0 atau pada saat pengumuman dilakukan. Reaksi yang positif pada saat dilakukannya pengumuman stock split menunjukkan bahwa pasar bereaksi menyerap informasi dengan cepat dan secara normal. Namun pada saat $t+1$ hingga $t+2$, respon pasar 
terus menurun. Rata-rata return tak normal sebelum pengumuman adalah 0,002, sedangkan sesudah pengumuman adalah 0,015, artinya terdapat peningkatan rata-rata return tak normal sesudah pengumuman stock split dilakukan oleh perusahaan non LQ45. Pengumuman stock split yang dilakukan oleh perusahaan non LQ45 mendapatkan reaksi positif dari investor. Hal tersebut ditunjukkan dengan terdapat peningkatan rata-rata return tak normal sesudah peristiwa terjadi. Investor menganggap pengumuman stock split menghasilkan keuntungan yang baik, sehingga investor memberikan reaksi setelah pengumuman stock split dilakukan.

Uji hipotesis ketiga dilakukan dengan normalitas data dengan menggunakan uji statistik kolmogorov-smirnov. Hal ini mengetahui data berdistribusi normal atau tidak. Apabila data telah berdistribusi normal, maka bisa dilanjutkan ke uji parametrik yaitu uji indpendent sample t-test untuk menguji perbedaan reaksi pasar antara perusahaan LQ45 dan non LQ45 atas pengumuman stock split. Hasil uji normalitas menunjukkan nilai asymp. Sig. (2tailed) 0,200 lebih besar dari 0,05, sehingga data sudah berdistribusi normal dan dilanjutkan ke uji parametrik yaitu independent sample t-test, dan dapat dilihat pada Tabel 5 . berikut.

Tabel 5. Hasil Uji Independent Sample T-Test

\begin{tabular}{lllll}
\hline Keterangan & $\mathrm{N}$ & Rata-rata & $\mathrm{t}$ & Sig. (2-tailed) \\
\hline LQ45 & 15 & 0,009 & $-0,152$ & 0,879 \\
Non LQ45 & 91 & 0,010 & -152 & \\
\hline
\end{tabular}

Sumber: Data Penelitian, 2019

Berdasarkan Tabel 5. menunjukkan rata-rata abnormal return perusahaan LQ45 sebesar 0,009 dan rata-rata abnormal return perusahaan non LQ45 sebesar 0,010. Nilai t sebesar -0,152 dan nilai asymp. Sig. (2-tailed) 0,879 lebih besar dari 0,05 maka hipotesis ketiga ditolak atau tidak terdapat perbedaan reaksi pasar antara perusahaan LQ45 dan non LQ45 atas pengumuman stock split. Hasil pengujian ini membuktikan bahwa tidak terdapat perbedaan reaksi pasar antara perusahaan LQ45 dan LQ45 atas pengumuman stock split. Hasil penelitian ini sesuai dengan penelitian dari Meylita \& Yasa (2015) yang menunjukkan bahwa peristiwa dari stock split yang dilakukan oleh perusahaan LQ45 maupun yang non LQ45 mendapatkan respon dari investor. Namun penelitian ini bertentangan dengan hasil penelitian yang dilakukan oleh Bajra \& Hasani (2012). Akibat dari stock split, harga saham perusahaan yang melakukan stock split menjadi lebih mudah dijangkau oleh investor. Reaksi yang sama diberikan oleh investor terhadap perusahaan yang memiliki status LQ45 maupun yang non LQ45 atas pengumuman stock split

\section{SIMPULAN}

Hasil temuan penelitian ini, dapat disimpulkan yaitu terdapat perbedaan reaksi pasar pada perusahaan LQ45 sebelum dan sesudah pengumuman stock split. Begitu pula dengan perusahaan non LQ45 yang menunjukkan terdapat perbedaan reaksi pasar perusahaan non LQ45 sebelum dan sesudah pengumuman stock split. Rata-rata return tak normal sesudah pengumuman stock split lebih tinggi dibandingkan dengan sebelum pengumuman stock split. Perbandingan reaksi pasar antara perusahaan LQ45 dan non LQ45 menunjukkan 
tidak adanya perbedaan reaksi pasar antara perusahaan LQ45 dan non LQ45 atas pengumuman stock split dikarenakan antara perusahaan LQ45 dan non LQ45 direaksi sama oleh pasar, investor memberikan reaksi yang sama atas pengumuman stock split.

Penelitian ini memperkuat teori sinyal pada pengumuman stock split, hal ini dikarenakan diketahuinya pengumuman stock split oleh perusahaan LQ45 maupun yang non LQ45 sama-sama direaksi positif oleh pasar. Penelitian ini menggunakan abnormal return untuk mengukur reaksi pasar. Investor yang berkeinginan melakukan penjualan ataupun pembelian di sekitar peristiwa dari stock split, diharapkan dapat membeli saham sebelum pengumuman dilakukan dan dapat melakukan penjualan saham setelah pengumuman stock split dilakukan. Hal ini karena berdasarkan hasil penelitian, terjadi peningkatan abnormal return sesudah pengumuman stock split dilakukan. Penelitian selanjutnya diharapkan dapat menggunakan model pengukuran lain untuk menghitung reaksi pasar atas pengumuman stock split seperti trading volume activity.

\section{REFERENSI}

Adnyani, K. S. \& Putri, I. G. A. M. A. D. (2015). Pengujian kandungan Informasi pada Pengumuman pemecahan saham di Indonesia. E-Jurnal Akuntansi Universitas Udayana. 10(1), 63-77.

Artama, N. S. \& Wirakusuma, M. G. (2018). Perbedaan Reaksi Pasar atas Peristiwa Stock Split dan Reverse Stock Split. E-Jurnal Akuntansi Universitas Udayana. 23(2), 1225-1252.

Bajra, U. \& Hasani, B. (2012). Event Study on Stock Splits. International Journal of Interdisclipanary Research, 1(2), 37-43.

Griffin, C. H. (2010). Abnormal Returns and Stock Splits: The Decimalizedvs. Fractional System of Stock Price Quotes. International Journal of Business and Management, 5 (12), 3 -13. https://doi.org/10.5539/ijbm.v5n12p3

Hanafie, L., \& Diyani, L. A. (2016). Pengaruh Pengumuman Stock Split Terhadap Return Saham , Abnormal Return dan Trading Volume Activity. Jurnal Bisnis Dan Komunikasi, 3(2), 13-20.

Hartono, J. (2017). Teori Portofolio dan Analisis Investasi. Edisi Kesebelas. Yogyakarta: BPFE.

Hossain, S. (2017). Market Reaction aroundthe Event of a Stock Splits: An Analysis on the Dhaka Stock Exchange. International Journal of Business and Management. 12(7), 212-222. https://doi.org/10.5539/ijbm.v12n7p212

Hua, L., \& Ramesh, S. (2013). A Study on Stock Split Announcements and its Impact on Stock Prices in Colombo Stock Exchange (CSE) of Sri Lanka. Global Journal of Management and Business Research Finance, 13(6), 234247.

Jannah, W., \& Ady, S. U. (2017). Analisis Fundamental, Suku Bunga, dan Overconvidence Terhadap Pengambilan Keputusan Investasi Investasi pada Investor di Surabaya. Jurnal Bisnis dan Manajemen, 1(2), 138-156. 
Jain, A., \& Robbani, M. (2013). The effect of stock split announcements on abnormal returns during a financial crisis. Journal of Finance and Accountancy. 4(11), 1-11.

Desai. (2016). Impact of Stock Split on Share Prices. International Journal of Recent Scientific Research, 7(5), 11419-11422.

Kalay, A. \& Kronlund, M. (2012). Stock Split: Information or Liquidity?. International Journal of Business and Management. 5(23), 112-128.

Karim, M. A. (2018). Market Reaction To Split Announcements: Rational Response or Behavioural Bias?. Academy of Accounting and Financial Studies Journal. 22(2), 1-15.

Khajar, I. (2016). Analisis Stock Split Terhadap Harga Saham Dan Volume Perdagangan Saham Indek Lq-45 Periode 2010 - 2016. Jurnal Keuangan Dan Perbankan, 20(3), 395-406. https:// doi.org/10.26905/jkdp.v20i3.290

Korir, S. K., Odhiambo, A. O., \& Wawire, P. (2016). Stock Splits and Performance of Firms Listed at the Nairobi Securities Exchange, Kenya. International Journal of Sciences: Basic and Applied Research (IJSBAR). 29(1), 168-178.

Li, X., Stork, P., \& Zou, L. (2009). An Empirical Note on US Stock Split Announcements, 2000-2009. Journal Economic and Business. 11(32), 111127.

Nadig, A. (2015). An Empirical Studyof Stock Split Announcements of Select BSE Sectors Using Event Study Methodology. SDMIMD Journal of Management, 6(1), 1-15.

Nagendra, M., \& Suresh Babu, M. (2018). Impact of Corporate (Different Stock Split Ratios) Action on Stock Price in India. International Journal of Research in Economics and Social Sciences (IJRESS), 8939(1), 2249-7382.

P, H. M., \& Yasa, G. W. (2015). Perbedaan Reaksi Pasar Atas Pengumuman Pemecahan Saham Pada Lq45 Dan NonLq45. Jurnal Ilmiah Akuntansi dan Bisnis. 10(2), 96-104.

Paramitha, D. (2019). Analisis Reaksi Pasar atas Pengumuman Stock Split. EJurnal Akuntansi Universitas Udayana. 27(3), 1897-1924.

Patel, M., Dave, M., \& Shah, M. (2016). Stock Price and Liquidity Effectof Stock Split: Evidence From Indian Stocks Market. International Journal of Management Research \& Review, 6 (8), 2249-7196. Retrieved from www.ijmrr.com.

Pratama, I. G. S., \& Sudhiarta, G. M. (2014). Analisis Perbandingan Abnormal Return Saham Sebelum dan Sesudah Pengummuman Right Issue. EJurnal Manajemen Universitas Udayana, 3 (1), 243-257.

Putra, P. G. A., \& Suaryana, I. G. N. A. (2019). Reaksi Pasar atas Pengumuman Stock Split. E-Jurnal Akuntansi Univeritas Udayana. 27(2), 1448-1471.

Tabibian, S. A., \& Zhang, Z. (2018). Stock Split Announcement and Return Votality: Evidence from Malaysia. Journal of Ecenomic Research, 23(2018), 265-290.

Trijunanto, E. (2015). Analisis Pengaruh Pemecahan Saham(Stock Split) Terhadap Abnormal Return Saham Dan Likuiditas Saham Pada Perusahaan Yang Terdaftar Di Bursa Efek Indonesia (Bei) Periode 2011-2015. Jurnal Keuangan dan Perbankan. 22(13), 145-158. 
Utami, A. T. (2017). Analisis Trading Volume Activity dan Average Abnormal Return Sebelum dan Sesudah Melakukan Pemecahan Saham (Stock Split) Pada Perusahaan yang Terdaftar di Bursa Efek Indonesia. Jurnal Ekonomi dan Bisnis. 18(2), 164-173

Zhu, C. \& Chen, K. (2014). The Market Reaction to Stock Splits Announncement and The UnderlyingExplanations. SFU Summit-Institusional Repository. Journal of Ecenomic Research. 2(45), 155-169. 